\title{
What Results Achieve the Best Youth Athletes When They Became Seniors? Evidences from a Portuguese Female Artistic Gymnastics 40 Years' Period
}

\author{
Artur Romão Pereira ${ }^{1}$, Ana Faro ${ }^{1}$, David Stotlar $^{2}$ \& António Manuel Fonseca ${ }^{3}$ \\ ${ }^{1}$ FCDEF, Universidade de Coimbra, Portugal \\ ${ }^{2}$ School of Sport \& Exercise Science; University of Northern Colorado, USA \\ ${ }^{3}$ CIFI2D, Faculdade de Desporto, Universidade do Porto, Portugal \\ Correspondence: Artur Romão Pereira, Faculdade de Ciências do Desporto e Educação Física da Universidade \\ de Coimbra, Estádio Universitário de Coimbra, Pavilhão III, Santa Clara, 3040-156 Coimbra, Portugal. Tel: \\ 351-239-802-770. E-mail: arturromao@fcdef.uc.pt
}

Received: February 22, 2014 Accepted: April 23, 2014 Online Published: May 27, 2014

doi:10.5539/res.v6n2p85 URL: http://dx.doi.org/10.5539/res.v6n2p85

\begin{abstract}
The main purpose of this study was to examine the competitive pathways of the Portuguese female artistic gymnasts who achieved the first places in the earlier stages of their competitive categories, trying to understand how they were able or not to achieve the same level of competitive results over time. Further, it also was purpose of this study to analyze if there existed differences on that according to the level of performances reached by them at the beginning of their sport competitive careers. Therefore, were examined the sporting careers of all of the 282 female athletes who were classified at least once in the top six places of all national competitions organized by the Federation of Gymnastics of Portugal between 1971 and 2011 in the various existing categories (i.e., 10-11, 12-13, 14-15 and 16+ years old). Contrary to what it was found in most studies carried in other sports across several countries and sports, this study showed that a high percentage of the athletes who won the competitions at the beginning of their careers did it over again along their careers until the category of seniors, showing a high stability of the obtained results and a high longevity career. Therefore, it seems to suggest that the responsible persons by their sport training process (i.e., coaches and other club's staff) are very efficacious in identifying the more talented female gymnasts and/ or to support them along their sporting careers, also stressing the importance of investigating the strategies adopted to achieve it.
\end{abstract}

Keywords: artistic gymnastics, sport results, stability, talent, excellence

\section{Introduction}

In general, contemporary societies concede significant emphasis on sports performance excellence, focusing primarily on the results of greater visibility, and even ignoring others that are less observable in spite of they are very important, particularly as regards so as they lead to the occurrence of the first ones. In fact, many times more than the intrinsic value or importance of certain long-term goals and achievements, what is appreciated is the immediate result, in this case the concrete obtaining a first place or a win. That is, we are witnessing the rule of immediate, the now, the today, sometimes even at the expense of tomorrow.

In large measure, one of the reasons why this happens is that at the socio-political level there is currently an intense competition between countries around the world by winning a prestigious image of sovereignty and leadership of global impact through the performances and victories won by their athletes and teams in major international sports competitions such as the Olympic Games, World Championships, or other major competitions of international scope.

It is particularly visible today the sharp rivalry between countries from all continents for winning medals as a corollary of a powerful society that affirms through sport, originated the number of countries that have succeeded in winning medals is increasing also diversifying countries that can achieve gold medals (Bosscher, de Knop, van Bottenburg, \& Shibli, 2006). Consequently, most countries are deeply committed to organizing and developing programs to identify exceptionally talented athletes, even at very young ages, and so they can concentrate the 
available resources on particularly promising individuals and promote their development oriented for a particular sport (Abernethy, 2008).

According to Baker and Schorer (2010), properly structured and organized programs of identification and development of sporting talent began to be developed since the middle of last century, particularly for countries like the German Democratic Republic, the Soviet Union, Romania and Bulgaria, which had the first successes in their application, to which more recently succeeded other countries, like the United States, Australia and China, also successfully. Indeed, Régnier, Salmela and Russell (1993) reported that since the 1950s and 1960s, the need to identify and invest in young people with possibilities to achieve high sports performances was a concern of national governing bodies, federations, clubs and coaches, because it was understood that thinking up a system for sports training without considering the talent recruitment hypothecate a good deal of possibilities to get far in high level sport (Marques, 1993).

In fact, being the sport practice so valued and the results of merit so difficult to achieve, requiring long periods of training time and investment of considerable resources to achieve these purposes, any means that can be found to accelerate the acquisition of experience and ability to make learning more efficient, will be exceptionally valuable for athletes coaches, officials and administrators (Abernethy, 2008).

In this sense, several authors (e.g., Vaeyens, Güllich, Warr, \& Philippaerts, 2009) highlight that the majority of countries try to develop properly systematized structures in order to achieve identify talented athletes and to promote their development in a particular sport. Even so, according to the some authors, the prognosis, with some years in advance, of the next generation of sports experts and the best way to encourage their development, remains problematic. Indeed, as also warn Vaeyens et al. (2009), although many young people show potential qualities in order to become experts in a particular sport, only a minority of them reaches the international sporting excellence.

It seems to be important that the knowledge about the variables and mechanisms associated with the identification, development and demonstration of talent and sporting excellence factors continue to be deepened and used with due care and attention, while promoting and supporting the progress of sports careers that seek competitive success and obtaining excellent performances. The consistency and robustness of any training process geared towards obtaining excellent performances are subject to a constant action of imponderable social, family and personal factors. In other words, there are multiple and diverse physiological, somatic, cognitive, motivational, cultural or social factors, that, individually or in interaction with each other, play a pivotal and catalyst role in the career of individuals who can achieve high level sport performances. Therefore, is important to perceive the complexity and multidimensionality of the route to success, i.e., the intricate and difficult barriers that are necessary to overcome throughout the long way to achieve the wanted levels of excellence in competitive performance.

Marques (1993) also stressed the need for seeing the sports performance as a complex entity as well to study it considering its bio-psycho-social determinants, i.e., through a multidimensional approach, which can also contribute to identifying the talent from the observation of certain assumptions considered decisive for success. The possible lack of objectivity and consistency in this process will necessarily lead to the occurrence of a defective choice, which subsequently would impedes to obtain the desired success. Therefore, is necessary to get a more precise and detailed characterization of the main variables and mechanisms required for obtaining the success in each sport in order to achieve greater objectivity in the identification and selection of talent for their realization because, knowing accurately characterize the traits that mark the expression of talent in each sport, would treat of, in due course, to analyze the characteristics of young sportsmen by reference to the demands of sport (Marques, 1993).

However, in spite of the efforts carried to improve the systems for identification and detection of sporting talents at young ages and to provide the subsequent support to these athletes, the analysis of the research produced in this area reveals that there are several authors to warn that obtaining high performances early in sports training is not always matched by obtaining high level marks at a later stage of the sports career, particularly in adulthood (e.g., Durand-Bush \& Salmela, 2001; Régnie et al., 1993; Vaeyens et al., 2009).

Hahn (1988) even stated that only $10-20 \%$ of athletes who excel at younger ages can achieve competitive elite when adults, similar results to those found by Brito, Rolim, and Fonseca (2004), when analyzing the Portuguese rankings of the various specialties of track and field over two decades in all age groups of women and found that only $11 \%$ of those who had occupied the five first places in the children's level (i.e., under 13 years old) also achieved it later in senior (i.e., 18+), not being very different from the percentages found for the other two age categories analyzed (i.e., $13 \%$ for under 15 years, and $26 \%$ for the under 17 years). 
Similarly, more recently, also the study of Barreiros, Côté, and Fonseca (2012) showed that the correspondence between the high sports results obtained in the pre-junior level and the results obtained later by the same athletes when adults was not as high as desirable, i.e., the percentage of athletes who, having excelled in youth and been summoned to join their national teams, managed to achieve again high level results when adults and being called again to integrate national teams was only $34 \%$ in football, $28 \%$ in judo, $30 \%$ in swimming and $56 \%$ in volleyball.

Still, the analysis of the results available in the literature in this respect, seems to emphasize the notion that this rate is not homogeneous across different sports, varying not only according to the sex of the investigated athletes, but also with the associated contexts and characteristics of their practiced sports, whether in terms of country, but also the type of sport itself. For example, this rate seems to be quite different when considering eminently individual sports or team sports. Similarly, also the fact that the competitive structure of a sport point to the age of peak performance succeeds to late $20 \mathrm{~s}$ or around the 20 s seems to correspond to different percentages of athletes who confirm the results achieved at the beginning of their international competitive careers.

For example, in a study that Barreiros and Fonseca (2012) analyzed the sport paths of all athletes born between 1974 and 1983 who joined the Portuguese national teams of soccer, volleyball, swimming and judo, is possible to see that the percentage of athletes who took part in the major world competitions (i.e., European and World Championships and Olympic Games) without ever having been international in young ages was $27 \%$ for football and $15 \%$ for volleyball, but in individual sports that happened in much lower expression with only $6 \%$ for judo and $0 \%$ for swimming.

On the other hand, in a recent study developed in artistic gymnastics by Pereira, Faro, Stotlar, and Fonseca (2013), which involved a retrospective analysis of the sport paths of all female gymnasts who represented the Portuguese national team in a 40-year period, it was found that all athletes who participated in the Olympic Games began to stand out from the early start of their sporting careers.

So, it seems to be important carry further research in this area to try to better understand the reasons why it is so high the percentage of athletes who obtain the highest performances in adults without having achieved in the early stages of their sporting careers and because that varies so much from sport to sport, because this knowledge would be critical to improving the quality and effectiveness of the programs of identification and selection of sporting talent.

However, it seems equally important to seek realize how many athletes who excel in the initial stage of their sporting careers but, for one reason or another, do not achieve later outstanding sports results.

In fact, if in the first case we consider that the emphasis is more oriented to the effectiveness of the system (i.e., coaches, support staff, managers, clubs, associations, etc...) in the identification of the sports talent (i.e., how the system can identify at an early stage of their careers the athletes who later, i.e., in adults, would be able to obtain the best sporting results) in the second case the attention is more geared to its effectiveness as a support for the development of those talents (i.e., how the system can help those who have showed conditions to achieve high sports results at an early stage of their sporting careers to develop their skills and achieve later, i.e., in adults, high level sports performances) .

Moreover, few studies adopted this approach (e.g., Barreiros et al., 2012; Brito et al., 2004; Schumacher, Mroz, Mueller, Schmid, \& Ruecker, 2006), and none of them was developed in artistic gymnastics, despite this being one of the oldest and most traditional sports in Western societies. Furthermore, the artistic gymnastics corresponds to a very specific reality, because it is one of the sports in which the peak performance occurs at younger ages, reason why there's a reasonably probability to find different results than those found in the previously referred studies.

Therefore, the present study sought to analyze in the Portuguese female artistic gymnastics context and in a broad range of time, the competitive pathways of athletes who obtained the highest performances in youth official competitions at the national level, examining the development of their competitive careers. More specifically, it was purpose of this study to investigate until when the athletes who achieved the first places in the youth competitive categories maintained the same level of competitive results throughout their careers.

\section{Method}

After being granted the necessary authorization to conduct this study as well the ethical approval, it were analyzed all individual classifications in the nationwide competitions organized by the Federation of Gymnastics of Portugal (FGP) between 1971 and 2011 of the various existing categories; i.e.; beginners (10-11 years old), juvenile (12-13 years old), juniors (14-15 years old) and seniors (16 years old and plus), based on which it was created a database with the name, date of birth and participated competitions of all athletes enrolled in the FGP. 
However, considering the objectives set for this study, only the results of the 282 female athletes who were classified at least once in the top six of those competitions and, given their date of birth and time when this study was conducted, would have the opportunity to compete in all competitive categories were analyzed; i.e., from the previously created database, were removed all the athletes who, despite having obtained one of the first six places in at least one competition of the beginners, juvenile or junior categories in the time period analyzed, they still had not age enough to compete at the senior level.

Also according to the objectives of the study, were considered three groups: i) the group of athletes who won the competitions; ii) the group of athletes who, not having won, still occupied one of the other podium places, i.e., who achieved $2^{\text {nd }}$ or $3^{\text {rd }}$ places; and iii) the group of athletes who occupied one of the remaining places up to the sixth, i.e., they finished in $4^{\text {th }}, 5^{\text {th }}$ or $6^{\text {th }}$ places.

It was determined the $6^{\text {th }}$ as the minimum place to consider because, in accordance with the rules of the artistic gymnastics active during most of the period analyzed in this study, 6 were precisely the necessary athletes to constitute a team. Moreover, this criterion (i.e., obtaining a place in the top 6) was also observed in a previous study carried by Cafruni, Marques, and Gaya (2004) with Brazilian athletes from various sports as a criterion for determining the Brazilian gymnasts of the youth categories who would be able to meet the requirements of a high competitive performance.

Finally, to analyze the successful competitive career longevity of each athlete, it were considered the dates of the first and last competitions they were able to meet the requirements already presented, i.e., where they obtained a classification in the top six places.

\section{Results and Discussion}

The analysis of the competitive pathways of the 282 athletes in the sample of our study showed that 190 of them were classified at least once in the first six places in the competitions organized by FGP between 1971 and 2011 in the category of 10-11 years old, decreasing this number when it were considered the higher age categories: 179 in the 12-13 years old, 139 in 14-15 years old, and only 91 in 16+ years old (see Table 1).

Table 1. Number of gymnasts who occupied the first six places in each age categories

\begin{tabular}{lcccc}
\hline & $10-11$ years & $12-13$ years & $14-15$ years & $16+$ years \\
\hline 1 st place & 18 & 44 & 34 & 18 \\
$2^{\text {nd }}-3^{\text {rd }}$ places & 33 & 29 & 25 & 23 \\
$4^{\text {th }}-6^{\text {th }}$ places & 139 & 106 & 79 & 50 \\
Total & 190 & 179 & 138 & 91 \\
\hline
\end{tabular}

Furthermore, it was also possible to verify that the competitions of the 10-11 years old category were won by a much smaller number than the observed numbers for the two categories immediately above; i.e., if in the 10-11 years old category the first place was achieved by only 18 athletes, in the 12-13 years old category the number rose to 44 , and then decreased slightly to 34 in the 14-15 years old category. In the 16+ years old category the number declined again and were again only 18 athletes who have won competitions of this category during the examined period.

However, when we looked at how many athletes got the following classifications, both corresponding to the other two podium places (i.e., $2^{\text {nd }}$ or $3^{\text {rd }}$ place) and as the following (i.e., $4^{\text {th }}, 5^{\text {th }}$ or $6^{\text {th }}$ place), it was found a continued decline of those numbers. Indeed, we found that the number of athletes who won the top six places in the 16+ years old national competitions during the period 1971 to 2011 is less than half of the number of athletes who have won the top six places in the same 10-11 years category.

That is, it was found that, although the first six places in the younger categories were occupied by a higher number of athletes (e.g., in the 10-11 years old category approximately 2 out of every 3 athletes whose paths were analyzed in this study were able to achieve a place in the first six places at least once), which could reveal the existence of a highly competitive alternation in obtaining the best performance, when the analysis focused only on those who finished first in these competitions, it became clear that this was achieved by a relatively small number of gymnasts (e.g., in the same 10-11 years old category, the first place it was achieved by only $6 \%$ of the examined athletes, i.e., ten times less), thus suggesting that the alternation as regards the first place was not so high, being restricted to a limited set of athletes. 
When the analysis was focused in the $16+$ years old category, it became even more evident that the best places were only available to a relatively small number of athletes because, apart from just under $6 \%$ of examined athletes have managed to win a competition, even the first six places were reserved for no more than one in three of the athletes analyzed in this study.

These results can not be considered surprising, since that the in 16+ years old category age restrictions do not exist, a circumstance which, although it may allow the number of competitors with the ability to discuss the first places is higher, also allows those with more capabilities than their competitors can excel longer because, rather than what occurred in the previous categories, do not have to leave the category due to age; i.e., it is perfectly natural to observe a pyramid effect at this level, which leads that to the most important classifications are obtained for a smaller number of exceptional athletes, particularly when balance and competitiveness are not very high.

As previously mentioned, it was established as fundamental purpose of this study to try to understand the extent to which athletes who have the best results in the initial phases of their sports careers continue or not to excel throughout their sporting career, achieving results among the top six places.

Data analysis showed (see Table 2 and Figure 1) an high stability in achieving outstanding results by the athletes who began to stand out in the 10-11 years old category, because we found that, of the 18 athletes who won the competitions in that category, nearly $80 \%$ also won competitions in the 12-13 years old category (among the four who did not win competitions in 12-13 years old category, two have finished their sport careers at the 10-11 years category, one at the 12-13 years category and one at the 16+ years category, yet the latter two became international). Moreover, among those 18 athletes, more than 70\% won competitions in 14-15 years old category, with eight of them (i.e., approximately $45 \%$ ) having won competitions in all categories, including in the $16+$ years old category.

Table 2. Number of gymnasts who reached the first $6^{\text {th }}$ in the official nationwide competitions along their careers, according to the best place they reached in the 10-11 years old category

\begin{tabular}{|c|c|c|c|c|c|c|c|c|c|c|c|c|}
\hline & \multicolumn{4}{|c|}{$12-13$ years } & \multicolumn{4}{|c|}{$14-15$ years } & \multicolumn{4}{|c|}{$16+$ years } \\
\hline & $1^{\text {st }}$ & $2^{\text {nd }}-3^{\text {rd }}$ & $4^{\text {th }}-6^{\text {th }}$ & Total & $1^{\text {st }}$ & $2^{\text {nd }}-3^{\text {rd }}$ & $4^{\text {th }}-6^{\text {th }}$ & Total & $1^{\text {st }}$ & $2^{\text {nd }}-3^{\text {rd }}$ & $4^{\text {th }}-6^{\text {th }}$ & Total \\
\hline $\begin{array}{l}1^{\text {st }} \text { in } 10-11 \text { years } \\
(n=18)\end{array}$ & 14 & 2 & 0 & 16 & 13 & 2 & 1 & 16 & 8 & 3 & 2 & 14 \\
\hline $\begin{array}{l}2^{\text {nd }}-3^{\text {rd }} \text { in } 10-11 \text { years } \\
(n=33)\end{array}$ & 12 & 13 & 2 & 27 & 9 & 12 & 4 & 25 & 5 & 8 & 1 & 14 \\
\hline $\begin{array}{l}4^{\text {th }}-6^{\text {th }} \text { in } 10-11 \text { years } \\
(n=139)\end{array}$ & 14 & 10 & 45 & 69 & 10 & 7 & 29 & 46 & 4 & 10 & 14 & 28 \\
\hline
\end{tabular}

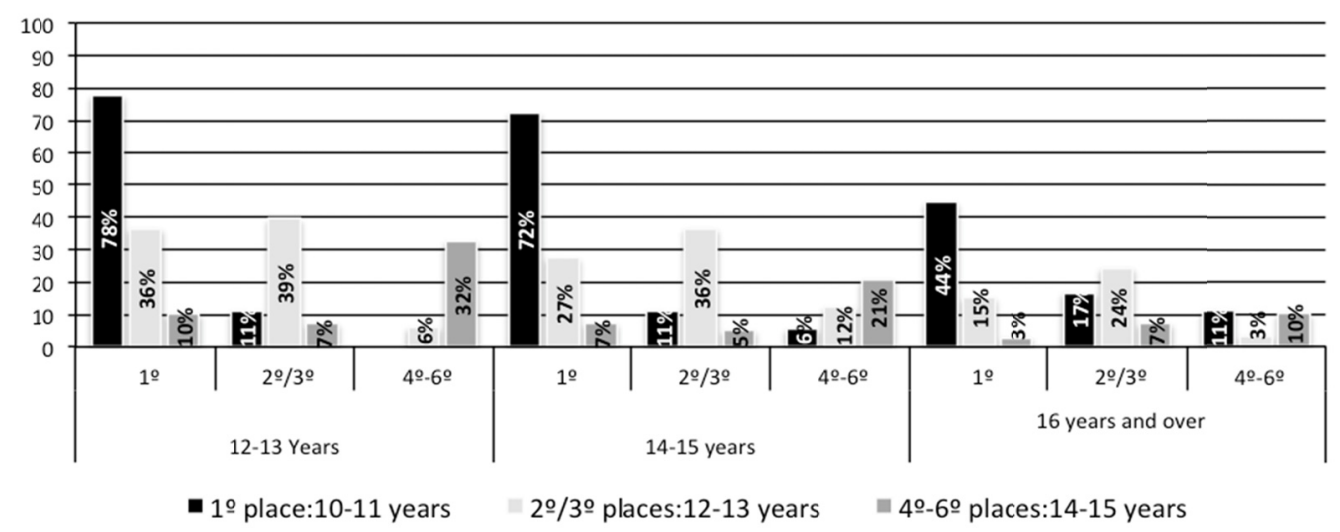

Figure 1. Percentage of gymnasts who reached the first $6^{\text {th }}$ in the official nationwide competitions along their careers, according to the best place they reached in the 10-11 years old category 
On the other hand, it was also possible to verify that the 33 athletes who, despite not having won any competition in the 10-11 years old category, finished in $2^{\text {nd }}$ or $3^{\text {rd }}$ place, a little over $35 \%$ were able to win at least one competition in 12-13 years old category, approximately $30 \%$ in the $14-15$ years old category and $15 \%$ in the $16+$ years old category. As for the 139 athletes who got a place between the $4^{\text {th }}$ and $6^{\text {th }}$ place in the $10-11$ years old category competitions, only $10 \%$ were able to win a competition in the $12-13$ years old category, $7 \%$ in the $14-15$ years old category and $3 \%$ in the $16+$ years old category.

Therefore, appeared to be clear that there is a high stability in the performance demonstrated by athletes because, besides having been clear that at least 3 out of 4 of the athletes who won competitions in the 10-11 years old category continued to get places among the top six in all categories, it was also possible to observe that, in general, they continued to win competitions throughout their competitive careers, with almost half of them winning competitions even in the 16+ years old category; on the other hand, among those who did not win competitions in the 10-11 years old category only a few were able to do it later.

The analysis of the competitive paths of athletes who won competitions in the 12-13 years old category (see Table 3 and Figure 2) showed a similar pattern, since among the 44 athletes who won competitions in that category approximately $60 \%$ also won competitions in the $14-15$ years old category and approximately $35 \%$ did it in the $16+$ years old category.

Table 3. Number of gymnasts who reached the first $6^{\text {th }}$ in the official nationwide competitions along their careers, according to the best place they reached in the 12-13 years old category

\begin{tabular}{|c|c|c|c|c|c|c|c|c|}
\hline & \multicolumn{4}{|c|}{ 14-15 years } & \multicolumn{4}{|c|}{$16+$ years } \\
\hline & $1^{\mathrm{st}}$ & $2^{\text {nd }}-3^{\text {rd }}$ & $4^{\text {th }}-6^{\text {th }}$ & Total & $1^{\text {st }}$ & $2^{\text {nd }}-3^{\text {rd }}$ & $4^{\text {th }}-6^{\text {th }}$ & Total \\
\hline $\begin{array}{l}1^{\text {st }} \text { in } 12-13 \text { years } \\
(n=44)\end{array}$ & 26 & 9 & 4 & 39 & 15 & 15 & 2 & 32 \\
\hline $\begin{array}{l}2^{\text {nd }}-3^{\text {rd }} \text { in } 12-13 \text { years } \\
(n=29)\end{array}$ & 6 & 12 & 3 & 21 & 3 & 6 & 5 & 14 \\
\hline $\begin{array}{l}4^{\text {th }}-6^{\text {th }} \text { in } 12-13 \text { years } \\
(n=106)\end{array}$ & 1 & 2 & 35 & 38 & 0 & 0 & 19 & 19 \\
\hline
\end{tabular}

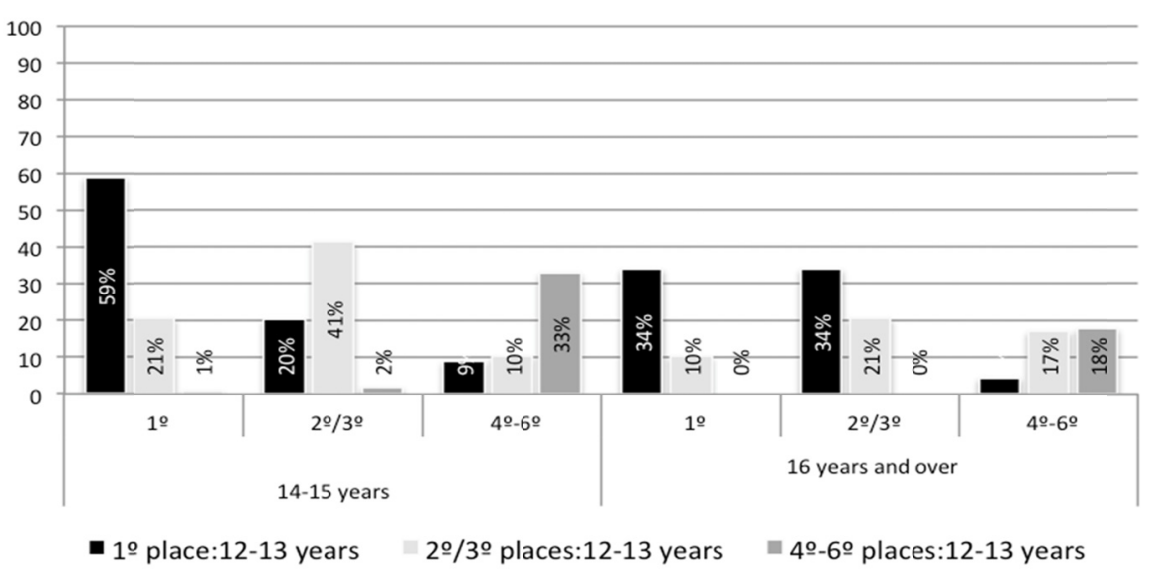

Figure 2. Percentage of gymnasts who reached the first $6^{\text {th }}$ in the official nationwide competitions along their careers, according to the best place they reached in the 12-13 years old category

On the other hand, among the 29 athletes who, having not won any competition in the 12-13 years old category, finished in $2^{\text {nd }}$ or $3^{\text {rd }}$ place, only about $20 \%$ were able to win a competition in the 14-15 years old category, reducing this percentage to $10 \%$ in the $16+$ years old category. Moreover, among the 106 athletes whose best rank in the 12-13 years old category was somewhere between the $4^{\text {th }}$ and $6^{\text {th }}$ place, only one (i.e., less than $1 \%$ ) managed to win a competition in 14-15 years old category and none has achieved it in the $16+$ years old category. 
Reinforcing the idea earlier mentioned about the stability of the results achieved by athletes whose paths were examined in this study, it was found that among the 44 athletes who won competitions in the 14-15 years old category, only four of them (i.e., less than $10 \%$ ) do not had previously obtained a place among the top six in the 10-11 years old category, a situation that only occurs once when considered the 14-15 years old category and does not occur in the $16+$ years old category; that is, seems to be virtually impossible for an athlete winning a competition in older age categories, particularly in the $16+$ years old category, if she did not do it previously (i.e., at the initial age categories).

From the available literature on the talent development in sport (e.g., Barreiros, Côté, \& Fonseca, 2013) arises the notion that early specialization should be considered very carefully because, although it is recognized that can lead to the sporting success (e.g., Law, Côté, \& Ericsson, 2007; Starkes, Deakin, Allard, Hodges, \& Hayes, 1996), is also associated with a higher prevalence of physical and emotional exhaustion (Strachan, Côté, \& Deakin, 2009) and injuries (Law et al., 2007) and may lead to situations of dropout and burnout (Fraser-Thomas, Côté, \& Deakin, 2008; Gould, Tuffley, Udry, \& Loher, 1996).

Therefore, it is probable that among the athletes who earlier start achieving outstanding results, most likely due not only to their intrinsic ability to do their sport but also to the pressures made accordingly by their 'surroundings' (e.g., coaches, other staff, officials, family), are frequent situations of burnout and dropout, which otherwise could contribute to explain the repeatedly observed fact that a high number of children and youth who excel at the beginning of their sporting careers does not get back equal prominence in more advanced ages (e.g., Barreiros et al., 2012; Brito et al., 2004; Hahn, 1988; Vayens et al., 2009).

However, in the present study, a particularly high number of athletes who achieved the best places in the early ages (i.e., in the 10-11 and 12-13 years old categories) continued to get it throughout their sporting careers, specifically at older ages (i.e., in 14-15 and 16+ years old categories), suggesting that the context of artistic gymnastics have quite different characteristics from those of other modalities.

Actually, it was quite clear that, in the Portuguese female artistic gymnastic, who excel at the beginning of their sporting careers continue to do it consistently throughout their competitive careers, which incidentally can find some echo in results from other studies developed with gymnasts, although from the rhythmic variant (e.g., Beamer, 2001; Law et al., 2007).

These results are then different from those reported in other studies carried with athletes of various other sports (e.g., cycling, football, judo, swimming, track and field, volleyball) that indicated the percentage of athletes who can maintain high levels of sports performance throughout their competitive careers, particularly when considering from it's beginning (i.e., from the earliest age groups), is much smaller. In spite of that, it's important to recall that artistic gymnastics is a sport in which the peak performance comes in much lower ages making normal the occurrence of an early specialization (Baker \& Côté, 2006), reason why this scenario should not be considered as a complete surprise.

As previously referred, the main objective of this study was to try to analyze the longevity and stability of the sports performance of athletes who excelled at early phases of their competitive careers, with the data analysis clearly demonstrating that, in general, the athletes who won the competitions in the 10-11 years old category, as well as in the 12-13 years old category, continued to do so throughout their careers.

Seeking to complement our research in this regard, it was understood that it would also be important, in addition to the analysis of the places obtained by athletes throughout their competitive careers in national competitions organized by FGP, examining their participation in the 14-15 and 16+ years old Portuguese national teams, as these categories are those in which the emphasis on sport results is more evident, contrary to what happen toward the 10-11 and 12-13 years old categories, understood essentially as more educational and developmental categories (for which are not even organized major international competitions such as the European or World Championships).

From this data analysis emerged once again (see Figure 3) evidences of the existence of a high stability of the results obtained by the athletes over time, since it was found that all athletes who won competitions in the 14-15 and $16+$ years old categories were also chosen to represent the respective national teams. If that information can not be considered surprising, because it is perfectly natural that the athletes who win the national competitions of a particular age category are selected to the national team in that category, the fact that the percentage of athletes who won competitions at the beginning of their competitive careers and who later came to represent the 14-15 and $16+$ years old national teams exceed $80 \%$ should receive attention. Moreover, even among those who did not win any competition in the 10-11 and 12-13 years old categories but obtained a place on the podium (i.e., $2^{\text {nd }}$ or $3^{\text {rd }}$ places), the percentage of athletes who later reached a performance level that deserved the call to represent the 
national team was clearly high, approaching up to 70\%. Naturally, when considering the information about the athletes who obtained $2^{\text {nd }}$ or $3^{\text {rd }}$ places in competitions of the higher age categories (i.e., 14-15 and 16+ years old) the percentage was even higher, ranging between $80 \%$ and $90 \%$.

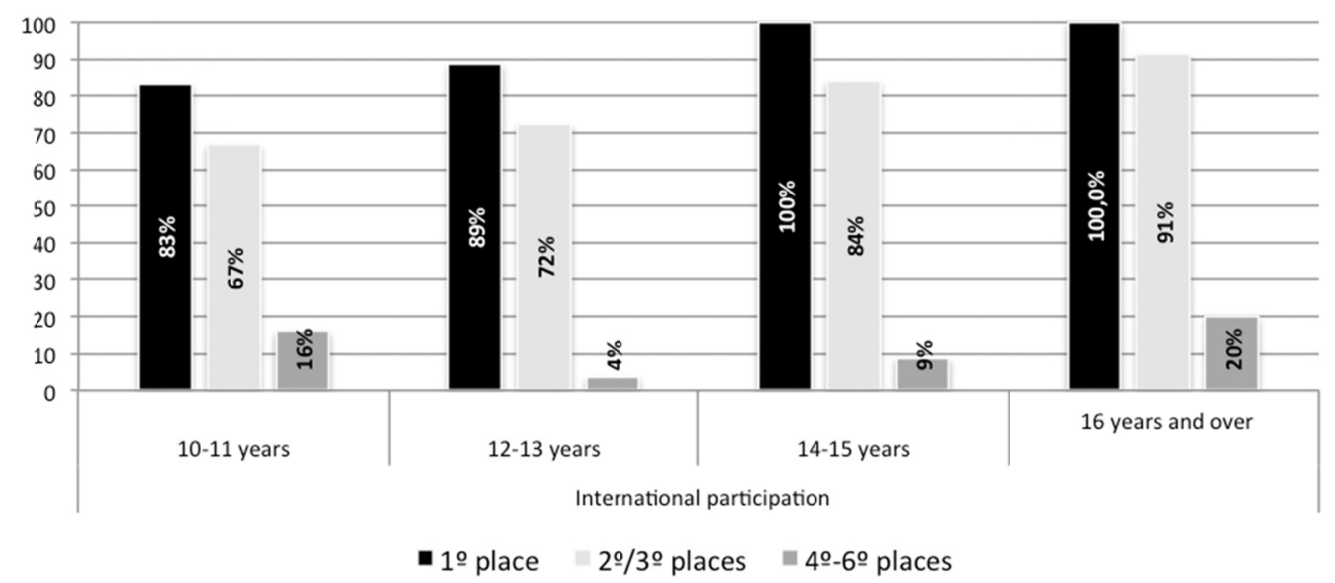

Figure 3. Percentage of gymnasts who participated in the 14-15 and 16+ years old national teams, according to the best place they achieved in the official nationwide competitions of each age categories

Thus, in relation to the longevity of careers, it may be considered that the results of this study also differ to some extent from those reported in other studies, as for example the one carried by Barynina and Vaitsekhovskii (1992) who found that swimmers who started earlier (i.e., at the 9-10 years old) in a more structured training context participated less time in the national teams and finished earlier than swimmers who only did it later (i.e., at 12-13 years old).

Overall, the results of the present study seem to suggest that, in the Portuguese female artistic gymnastics, the ability of the sports system (e.g., coaches, other staff, officials, parents, etc...) to promote the sport development of the athletes who early show their capacities is greater than what is achieved in other sports, because the percentage of athletes who 'lose' the route is much smaller than the recorded in other sports (e.g., Durand-Bush \& Salmela, 2001; Régnier et al., 1993; Vaeyens et al., 2009).

Furthermore, when considering the results of a previous study (Pereira et al., 2013), that adopted a retrospective approach to investigate when the Portuguese female artistic gymnast who reached the highest sport results when adults (i.e., representing the national teams in Olympic Games, World and European championships) begun to excel, and revealed this happened since the beginning of their sporting careers, it seems to show up that the sports system of the Portuguese artistic gymnastics (e.g., coaches, other staff, officials, parents, etc ...) demonstrates high efficacy in early identification and selection of the most talented young people for its practice, as well as later in promoting and developing their talent by creating the necessary conditions for them to remain involved in their practice and take advantage of contexts of practice with the required quality to reach high sports results.

Thus, recalling the huge demands, not only at the level of training loads, but also in what concerns to the required time for carry on this process (since, typically, the time spent in training and competition in artistic gymnastics is at least two to three times higher than the required by the practice of most other sports), seems unequivocally justified the importance of investigating in depth and detail the strategies developed by coaches, clubs, associations, to achieve those results.

Indeed, in spite of the results of the present study provide evidence for the notion that's possible to identify the sporting talents at an early age and provide them the necessary conditions to support them toward the excellence and the sporting success, there's not clear the best strategies to achieve it.

On the other hand, although most of the research in this area have found that there is a weak correlation between the sporting results that athletes achieve at the beginning and at the peak of their sporting careers (e.g., Barreiros et al., 2012; Barreiros \& Fonseca, 2012; Bloom, 1985; Bompa, 1995; Martindale, Collins \& Abraham, 2007; Schumacher et al., 2006; Vaeyens et al., 2009), the results of this study suggest that this might be not transversal 
to all sports and/ or this may be subject to improvement, reason why it seems important to investigate deeply this specific case.

\section{Conclusions}

The purpose of the present study was to investigate the competitive pathways of the gymnasts who obtained the highest performances in youth official national competitions organized by the Portuguese Federation of Gymnastics, examining the further development of their competitive careers.

In general, it was found a remarkable stability of the obtained results and a high longevity career, with a high percentage of the athletes who won the competitions at the beginning of their careers doing that over again along their careers until the category of seniors.

Therefore, these results, combined with the results of a previous study (Pereira et al., 2013) that showed that the Portuguese female artistic gymnasts who reached the best performances in the highest phase of their careers had already achieved it at the beginning of their careers, suggest the importance of trying to know in more detail what kind of strategies were used to identify those talents at an early age as well as to support them in developing their talent over time, because that information can be very useful to increase the quality of the sport process training, not only in the artistic gymnastics but also in other sports.

\section{References}

Abernethy, B. (2008). Introduction: Developing expertise in sport - how research can inform practice. In D. Farrow, J. Baker, \& C. MacMahon (Eds.), Developing Sport Expertise: Researchers and Coaches Put Theory into Practice (pp. 1-14). Abingdon, Oxon: Routledge.

Baker, J., \& Côté, J., (2006). Shifting training requirements during athlete development: Deliberate practice, deliberate play and other sport involvement in the acquisition of sport expertise. In D. Hackfort and G. Tenenbaum (Eds), Essential processes for attaining peak performance (pp. 92-109). Oxford: Meyer and Meyer Sport.

Baker, J., \& Schorer, J. (2010). Identification and Development of Talent in Sport - Introduction to the Special Issue. Talent Development \& Excellence, 2(2), 119-121.

Barreiros, A., Cotê, J., \& Fonseca, A. M. (2012). From early to adult sport success: Analyzing athletes' progression in national squads. European Journal of Sport Science. http://dx.doi.org/10.1080/17461391.2012.671368

Barreiros, A., Cotê, J., \& Fonseca, A. M. (2013). Sobre o desenvolvimento do talento no desporto: Um contributo dos modelos teóricos do desenvolvimento desportivo. Revista de Psicología del Deporte, 22(2), 489-494.

Barreiros, A., \& Fonseca, A. M. (2012). A retrospective analysis of Portuguese elite athletes' involvement in international competitions. International Journal of Sports Science \& Coaching, 7(3), 593-600. http://dx.doi.org /10.1260/1747-9541.7.3.593

Barynina, I., \& Vaitsekhovskii, S. (1992). The aftermath of early sports specialization for highly qualified swimmers. Fitness and Sports Review International, 2(4), 132-133.

Beamer, M (2001). The development of expertise in rhythmic gymnastics (Unpublished master's thesis). Queen's University, Kingston, Ontario, Canada.

Bloom, B. (1985). Developing talent in young people. New York; Ballantine.

Bompa, T. (1995). From childhood to champion athlete. Toronto: Veritas.

Bosscher, V., De Knop, P., Van Bottenburg, M., \& Shibli, S. (2006). A conceptual frame - Work for analysing Sports Policy Factors Leading to international sporting success. European Sport Management Quarterly, 6, 185-215. http://dx.doi.org/10.1080/16184740600955087

Brito, N., Fonseca, A. M., \& Rolim, R. (2004). Os melhores atletas nos escalões de formação serão igualmente os melhores atletas no escalão sénior? Análise centrada nos rankings femininos das diferentes disciplinas do atletismo ao longo das últimas duas décadas em Portugal. Revista Portuguesa de Ciências do Desporto, 4(1), $17-28$.

Cafruni, C., Marques, A., \& Gaya, A. (2004). Análise da carreira desportiva de atletas das regiões sul e sudeste do Brasil. Estudo dos resultados desportivos nas etapas de formação. Revista Portuguesa de Ciências do Desporto, 4(Sup.1), 218.

Durand-Bush, N., \& Salmela, J. (2001). The development of talent in sport. In R. N. Singer, H. A. Hausenblas, \& C. M. Janelle (Eds.). Handbook of Sport Psychology (pp. 269-289). John Wiley \& Sons, New York. 
Fraser-Thomas, J., Côté, J., \& Deakin, J. (2008). Examining adolescent sport dropout and prolonged engagement from a developmental perspective. Journal of Applied Sport Psychology, 20, 318-333. http://dx.doi.org $/ 10.1080 / 10413200802163549$

Gould, D., Tuffey, S., Udry, E., \& Loehr, J. (1996). Burnout in competitive junior tennis players: II. qualitative analysis. The Sport Psychologist, 10, 341-366.

Hahn, E. (1988). Entrenamiento con niños. Ediciones Martínez Roca. Barcelona.

Law, M., Côté, J., \& Ericsson, K. A. (2007). Characteristics of expert development in rhythmic gymnastics: A retrospective study. International Journal of Sport Psychology, 5, 82-103. http://dx.doi.org/10.1080 /1612197X.2008.9671814

Marques, A. (1993). A periodização do treino em crianças e jovens. Resultados de um estudo nos centros experimentais de treino da Faculdade de Ciências do Desporto e de Educação Física da Universidade do Porto. In A. Marques \& J. Bento (Eds.), As Ciências do Desporto e a Prática Desportiva (pp. 243-257). Porto: FCDEF, Universidade do Porto.

Martindale, R. J. J., Collins, D., \& Abraham, A. (2007). Effective Talent Development: The elite coach perspective in UK sport. Journal of Applied Sport Psychology, 19(2), 187-206. http://dx.doi.org/10.1080 /10413200701188944

Pereira, A., Faro, A., Stotlar, D., \& Fonseca, A. M. (2013). A retrospective study of the results of the best Portuguese female gymnasts in a period of 40 years. International Journal of Sports Science, 3(6), 204-210. http://dx.doi.org/10.5923/j.sports.20130306.04

Régnier, G., Salmela, J., \& Russel, S. (1993). Talent detection and development in sport. In R. N. Singer, M. Murphey, \& L. K. Tennant (Eds.), Handbook of Research on Sport Psychology (pp. 290-313). New York: Macmillan.

Schumacher, Y. O., Mroz, R., Mueller, P., Schmid, A., \& Ruecker, G. (2006). Success in elite cycling: A prospective and retrospective analysis of race results. Journal of Sports Sciences, 24(11), 1149-1156. http://dx.doi.org/10.1080/02640410500457299

Strachan, L., Côté, J., \& Deakin, J. (2009). "Specializers" versus "samplers" in youth sport: Comparing experiences and outcomes. The Sport Psychologist, 23, 77-92.

Vaeyens, R., Gullich, A., Warr, C., \& Philippaerts, R. (2009). Talent identification and promotion programmes of Olympic athletes. Journal of Sports Sciences, 2(13), 1367-1380. http://dx.doi.org/10.1080 /02640410903110974

\section{Copyrights}

Copyright for this article is retained by the author(s), with first publication rights granted to the journal.

This is an open-access article distributed under the terms and conditions of the Creative Commons Attribution license (http://creativecommons.org/licenses/by/3.0/). 